\title{
Influence of Gamma Rays on the Performance and Genetic Parameters for Grain Yield and Yield Attributes of Bread Wheat
}

\author{
I. S. El- Degwy ${ }^{\#}$ and M. S. Hathout* \\ Agronomy Dept., Faculty of Agriculture, Kafrelsheikh \\ University and "Sakha Research Station, Field Crops Res. Inst., \\ Agriculural Research Center (ARC), Egypt.
}

\begin{abstract}
Dure DRY seeds of two wheat cultivars; Sids 12 and Misr1 were subjected to gamma radiation doses at rates of 10,15 , and $20 \mathrm{KR}$. ${ }^{60} \mathrm{Co}$ used as a source of gamma rays at the Middle East Regional Radioisotope Center for Arab Countries at Dokki, Giza. Significant differences between irradiated and non-irradiated plants were detected for most of the studied characters in the $\mathrm{M}_{1}$ and $\mathrm{M}_{2}$ generations. The most beneficial dose was $10 \mathrm{KR}$. The impact of this dose was promising in grain yield and No. of spikes/ plant in both generations. High reduction in the mean values of plant height, spike weight and grain yield/ plant were obtained in response to higher does of gamma rays (20 KR) in $\mathrm{M}_{1}$ generation. While it improved No. of spikes/ plant, spike weight and grain yield in $\mathrm{M}_{2}$ generation, but grain yield was still less than that of the $10 \mathrm{KR}$. The two cultivars responded differently to different gamma radiation doses except grain yield in $\mathrm{M}_{1}$ and heading date in $\mathrm{M}_{2}$ generation as well as 1000-grain weight in the two generations. Maximum absolute value for No. of grains/ spike in $\mathrm{M}_{1}$ generation was occurred at $10 \mathrm{Kr}$ of gamma radiation for Sids 12. While, the same cultivar detected the heaviest spike weight under $15 \mathrm{KR}$. Wheat grains of Misr 1 treated with either 10 or $15 \mathrm{KR}$ recorded the highest No. of spikes/ plant in $\mathrm{M}_{1}$ generation. The most desirable value for grain yield/ plant $(30.4 \mathrm{~g})$ was obtained when Misr1 wheat cultivar subjected to low gamma ray dose $(10 \mathrm{KR})$ in the second mutagenic generation. In general, all the studied genetic parameters viz. $\sigma^{2} \mathrm{~g}, \mathrm{GCV}, \mathrm{PCV}, \mathrm{h}^{2} \mathrm{~b} . \mathrm{s}$ as well as genetic advance from selection was higher and folded several times in case of irradiated plants compared with the control. These indicated that the efficiency of gamma radiation doses in inducing genetic variation allowing the wheat breeder to improve wheat yield and its attributes through this method. The desirable genetic advance was found to be associated with high heritability estimates in case of spike weight and No. of spikes/ plant. It is concluded from this study that mutation/ variability in wheat can be created through the three mutagenic treatments of gamma rays and various quantitative traits would be improved using gamma rays.
\end{abstract}

Keywords: Gamma-rays, Genetic parameters, Wheat, Yield and yield components, Genotypes by gamma rays interaction.

\footnotetext{
${ }^{\#}$ Correspondence author e- mail: iseldegwy@yahoo.com
} 
Wheat (Triticum aestivum L.) is one of the most important cereal crops, used in human consumpation and livestock feed in Egypt. Irradiation of seed materials with gamma rays is of interest for crop breeders as a new source of genetic variability. Gamma irradiation was applied for producing mutant wheat cultivars within a wide dosage range from 15 to $350 \mathrm{~Gy}$, however the main part of released cultivars has been developed using gamma radiation within the dosage range from 200 to $300 \mathrm{~Gy}$ (Kozub et al., 2013). The use of the ionizing radiation technology may be considered as a revolution in agronomic research, especially in plant breeding and crop production (Madiha Jamil \& Khan, 2002). Irradiation can be considered an effective source for generating genetic diversity among plants; this genetic diversity is a basic perquisite for successful plant breeding program (Brunner, 1995).

Wheat cultivars responded differently to different gamma radiation doses. Several workers reported that low doses of gamma rays have positive effects on the plants; Amin (2003), Maity et al. (2005), Melki \& Marouni (2009) and Shubhra et al. (2013). Days to earing initiation significantly increased due to various doses of radiations (Rahm et al., 2003). Number of days to heading was apparently increased by each increment in radiation intensity from 5, 10, 20, up to $25 \mathrm{KR}$ compared with control (Madiha Jamil \& Khan, 2002). Plant height was retarded as the radiation doses were increased from 100, 200, 300 up to $400 \mathrm{~Gy}$ (Kim et al., 2007). Low doses of gamma radiation from 0.01 to $0.10 \mathrm{KGy}$ reduced plant height and 1000 -grain weight, while it improved number of ear bearing tillers, grain number and grain yield (Singh \& Datta, 2009). Among 3 gamma radiation doses; 20, 25 and $30 \mathrm{KR}$, Shubhra et al. (2013) reported that $20 \mathrm{KR}$ was the most beneficial dose. The impact of this dose was promising in days to flowering, plant height, test weight, and grain yield /plant while, high reduction in the mean value for all the studied traits were recorded under higher dose (30 KR). High gamma irradiation doses caused high reduction in wheat plant height and spike length (Farag \& El-Khawaga, 2013). The ranges in the $\mathbf{M}_{1}$ and $\mathbf{M}_{2}$ generation were wider than that in the control for plant height, number of spikes/ plant, spike length, number of spikelets/ spike, number of grains/ spike, 100-grain weight and grain yield (Morad et al., 2011).

The highest genotypic and phenotypic coefficient of variance was observed in $\mathrm{F}_{2} \mathrm{M}_{2}$ population for No. of spikelets/ spike, No. of grains/ spike, No. of spikes/ plant, 1000-grain weight and grain yield/ plant (Mahantashivayogayya et al., 2003). They also reported that the highest genetic advance was observed in treated populations for No. of spikelets / spike, No. of grains/ spike and 1000grain weight. The expected PCV was higher than GCV in $\mathrm{M}_{2}$ generation for all the studied characters after irradiation with $15 \mathrm{KR}$ gamma rays dose (Mahantashivayogayya et al., 2003). Subjected wheat grains to $25 \mathrm{KR}$ increased the values of phenotypic and genotypic coefficients of variation as well as heritability for most of the studied characters in $\mathrm{M}_{2}$ of two wheat cultivars compared with 20 and 15 doses (Kassem \& Naser, 1995). Heritability estimates 
in $\mathrm{M}_{2}$ generation were high and reached to more than $90 \%$ for plant height, No. of spikes/ plant, spike length, No. of spikelets/ spike and No. of grains/ spike (Morad et al., 2011). The objective of this investigation was to:

- Study the effect of gamma irradiation on some yield and yield indices of Sids 12 and Misr1 wheat cultivars.

- Determine the proper dose of gamma radiation for inducing beneficial genetic variability in wheat.

- Throw light on the response of different quantitative characters of wheat in regard to genetic parameters under irradiated and non-irradiated plants and its impact in plant selection procedure.

\section{Materials and Methods}

The present investigation was carried out at the Experimental Farm, Faculty of Agriculture, Kafrelsheikh University, Egypt during the two growing seasons of 2011/2012 and 2012/2013. Dry seeds of two Egyptian wheat cultivars, i.e. Sids 12 and Misr 1 were subjected to gamma radiation at the rate of 10, 15 and $20 \mathrm{KR}$ at the Middle East Regional Radioisotope Center for Arab Countries at Dokki, Giza. The treated and non-treated seeds (control) were grown to raise $M_{1}$ plants in a complete randomized block design with four replications. Each experimental plot consisted of 25 rows. Each row was 3 meter long. The distance between rows was $25 \mathrm{~cm}$ while the plant to plant distance within row was $15 \mathrm{~cm}$. The Cultural practices were performed as recommended. Fifty plants were randomly selected in each $\mathrm{M}_{1}$ treatment for growing $\mathrm{M}_{2^{-}}$generation.

In 2012/2013 the seeds of each of the 50 selected $\mathrm{M}_{1}$ plants were grown in a progeny row trial with three replications. Row to row and plant to plant distance were the same of $\mathrm{M}_{1}$ generation. To determine $\mathrm{M}_{2}$ micro-mutations, observations on various quantitative traits were recorded on all the plants in each treatment. The following observations were recorded: Heading date (day), plant height $(\mathrm{cm})$, spike length $(\mathrm{cm})$, No. of spikelets/ spike, No of grains/ spike, No. of spikes/ plant, spike weight, 1000-grain weight (g) and grain yield (g/plant).

$\mathrm{M}_{1}$ data were statistically analyzed according to the regular complete randomized block design, after the mean of each plot was calculated, Duncan's multiple range test was used for the comparison between treatment means (Duncan, 1955). In $\mathbf{M}_{2}$, micro-mutations were indicated by the calculated measurement of the variation in each Phenotypic (PCV) and genotypic (GCV) coefficients of variability (estimated according to Burton, 1952), the expected genetic advance from selection (as reported by Johnson et al., 1955), broad sense heritability (following to Singh \& Choudhary, 1985) for irradiated and non-irradiated plants. 


\section{Results and discussion}

First mutagenic generation

Varietal differences and gamma rays effects

Data presented in Table 1 indicated that wheat cultivars were differed in all studied traits. Moreover, Misr1 exceeded Sids 12 wheat cultivar in plant height, No. of days to heading and number of spikes/ plant. While, Sids 12 significantly surpassed Misr1 in the remaining six characters.

Results in Table 1 show significant differences among gamma radiation treatments for most of the studied traits. All doses were quite effective in inducing genetic variability. Higher radiation intensity $(20 \mathrm{KR})$ delays maturity by increasing days to heading. On the other hand, adverse effects on days to heading were produced under low dose of gamma radiation. Similar results were obtained by Hassan et al. (1988) and Madiha Jamil \& Khan (2002). Previous results indicated that days to ear initiation were significantly increased due to various doses of radiation (Rahm et al., 2003).

Wheat grains irradiated with low dose $(10 \mathrm{KR})$ of gamma radiation surpassed the other two irradiation doses and the control in plant height. While, high gamma irradiation doses caused high reduction in wheat plant height. The stimulatory effect of gamma irradiation at low doses was reported by several workers such as Farag \& El-Khawaga (2013) and Shubhra et al. (2013). These results were, in general, agreement with those of Kim et al. (2007). They reported that plant height was retarded as the applied dose of gamma increased from 100 up to $400 \mathrm{~Gy}$.

Non significant differences in the mean values for No. of grains/ spike were observed as a result of different gamma rays doses. This trend was also found for spike length, No. of spikelets/ spike and 1000-grain weight. Previous results showed that No. of gains/ plant was not significantly affected by irradiation intensity (Madiha Jamil \& Khan, 2002). No increase over the control in No. of grains/ spike was observed under the influence of gamma irradiation (Irfaq \& Nawab, 2003).

Large variation among gamma radiation doses were detected for No. of spikes/ plant. Wheat grains treated with low doses $(10 \mathrm{KR})$ of gamma irradiation exceeded the other two treatments and the control in such trait. In this connection, Abdel-Hady $\&$ Ahmed (2004) stated that low doses of 150 Gy seemed to have a stimulatory effect on agronomic traits of four wheat cultivars in the first mutagenic generation. Several researchers reported that when used at low doses, gamma rays have positive effect on the plants (Azer, 2001 and Maity et al., 2005). The same stimulative effects of gamma irradiation on No. of spikes/ plant were also reported by Melki \& Marouni (2009) on wheat plants treated with 20 Gy. By comparing the mean values of various doses it was found that spike weight was significantly increased due to various doses of radiation compared with the control (Table 1).

Egypt. J. Agron. 36, No. 1 (2014) 
INFLUENCE OF GAMMA RAYS ON THE PERFORMANCE ...

\begin{tabular}{|c|c|c|c|c|c|c|c|c|c|}
\hline 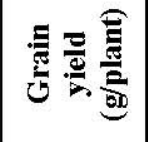 & $\begin{array}{l}\text { है } \\
\text { ले }\end{array}$ & $\begin{array}{l}\infty \\
\infty \\
\end{array}$ & $\begin{array}{l}8 \\
m \\
2\end{array}$ & 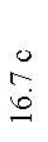 & $\stackrel{*}{*}$ & $\stackrel{\pi}{\stackrel{\sim}{\sim}}$ & $\begin{array}{l}0 \\
\infty \\
\end{array}$ & $\underset{*}{*}$ & $\stackrel{2}{a}$ \\
\hline 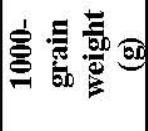 & $\stackrel{8}{y}$ & $\stackrel{\vec{J}}{\vec{\forall}}$ & $\begin{array}{l}\infty \\
\stackrel{0}{+}\end{array}$ & $\begin{array}{l}8 \\
y\end{array}$ & $\stackrel{2}{z}$ & $\begin{array}{l}0 \\
0 \\
0 \\
i\end{array}$ & $\begin{array}{l}\stackrel{0}{Z} \\
\dot{8}\end{array}$ & $\underset{*}{*}$ & $\stackrel{2}{a}$ \\
\hline 紊焉 & $\begin{array}{c}0 \\
\text { in }\end{array}$ & $\frac{8}{8}$ & $\begin{array}{l}0 \\
9 \\
0\end{array}$ & $\begin{array}{l}0 \\
\text { ते } \\
0\end{array}$ & $\stackrel{*}{*}$ & $\stackrel{2}{2}$ & $\stackrel{0}{\ddot{q}}$ & $\underset{*}{*}$ & $\stackrel{*}{*}$ \\
\hline 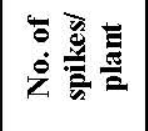 & $\begin{array}{l}8 \\
8 \\
0 \\
i\end{array}$ & $\stackrel{\infty}{?}$ & $\frac{\pi}{i}$ & $\begin{array}{c}0 \\
+ \\
+\end{array}$ & $\stackrel{*}{*}$ & $\begin{array}{l}\text { Pे } \\
\stackrel{+}{+}\end{array}$ & $\begin{array}{l}\tilde{\sigma} \\
0 \\
0\end{array}$ & $\stackrel{*}{*}$ & $\stackrel{*}{*}$ \\
\hline 它言畜 & $\frac{2}{\circ}$ & 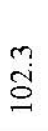 & $\stackrel{m}{m}$ & $\stackrel{y}{1}$ & $\stackrel{2}{z}$ & $\frac{\stackrel{\sigma}{+}}{\stackrel{\Xi}{\sigma}}$ & $\begin{array}{l}0 \\
\infty \\
\infty \\
\infty\end{array}$ & $\stackrel{*}{*}$ & $*$ \\
\hline 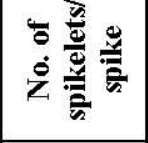 & $\overrightarrow{\mathrm{d}}$ & ભ̣. & $\underset{d}{\stackrel{\Delta}{d}}$ & $\underset{\mathrm{N}}{\mathrm{N}}$ & $\stackrel{2}{Z}$ & $\begin{array}{l}\pi \\
\stackrel{\sigma}{N}\end{array}$ & $\begin{array}{l}0 \\
\tilde{y} \\
\tilde{y}\end{array}$ & $\stackrel{*}{*}$ & $\stackrel{*}{*}$ \\
\hline 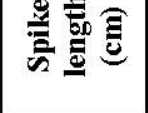 & $\stackrel{m}{m}$ & $\stackrel{\vec{\imath}}{\vec{\imath}}$ & $\stackrel{b}{\stackrel{c}{l}}$ & $\stackrel{n}{m}$ & $\stackrel{2}{2}$ & 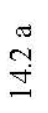 & i & $\stackrel{*}{*}$ & $\stackrel{*}{*}$ \\
\hline 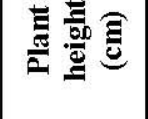 & $\begin{array}{l}\frac{\pi}{n} \\
m \\
\text { a }\end{array}$ & $\begin{array}{l}n \\
n \\
n\end{array}$ & $\begin{array}{l}\stackrel{0}{0} \\
\dot{a}\end{array}$ & $\frac{0}{10}$ & $\stackrel{*}{*}$ & $\begin{array}{l}0 \\
m \\
\infty \\
\infty\end{array}$ & $\begin{array}{l}\pi \\
\stackrel{\pi}{+}\end{array}$ & $\stackrel{*}{*}$ & * \\
\hline 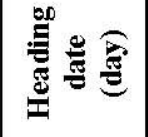 & $\begin{array}{l}0 \\
\text { îj } \\
\text { O }\end{array}$ & $\stackrel{0}{\Omega}$ & $\begin{array}{l}0 \\
\text { N } \\
\text { Ȯ } \\
\end{array}$ & $\begin{array}{l}\stackrel{\sigma}{\circ} \\
\stackrel{0}{0}\end{array}$ & $\stackrel{*}{*}$ & $\begin{array}{l}0 \\
0 \\
8\end{array}$ & $\begin{array}{c}\tilde{m} \\
\stackrel{m}{0} \\
\stackrel{0}{0}\end{array}$ & $\stackrel{*}{*}$ & $\stackrel{*}{*}$ \\
\hline \multirow{2}{*}{ 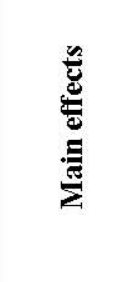 } & 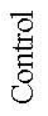 & $\begin{array}{l}\frac{1}{1} \\
\frac{1}{0}\end{array}$ & $\begin{array}{l}a \\
a \\
n\end{array}$ & $\begin{array}{l}\sqrt[1]{11} \\
\stackrel{\sim}{1}\end{array}$ & 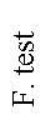 & $\frac{1}{\frac{n}{n}}$ & $\overrightarrow{\sum_{i}^{n}}$ & 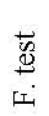 & $\begin{array}{l}0 \\
凶 \\
0\end{array}$ \\
\hline & \multicolumn{5}{|c|}{ 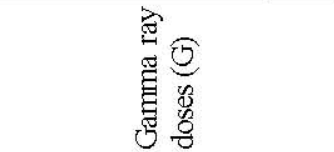 } & \multicolumn{3}{|c|}{ 量 } & 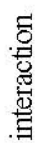 \\
\hline
\end{tabular}

Egypt. J. Agron. 36, No. 1 (2014) 
Grain yield was significantly increased under low dose of gamma radiation ( $23.8 \mathrm{~g} /$ plant) and surpassed the other two irradiation doses, but it was statistically equal the control. Similar results were obtained by Lapochkina (1998), Singh \& Data (2009) and Farag \& El-Khawaga (2013). Previous results showed that gamma rays applied at doses of 50,100 and 150 Gy had a negative effect on plant height, number of productive tillers, spike length and grain yield/ plant in $\mathbf{M}_{1}$ and $\mathrm{M}_{2}$ generations of three wheat cultivars (Rachovska \& Dimova, 2000).

To sum up, wheat grains irradiated with low doses of gamma radiation were early heading and exceeded the high dose and the control in each of plant height, number of spikes/ plant and grain yield. While, high gamma radiation dose caused adverse effects for such traits.

Effect of interaction between cultivars and gamma rays in $M_{1}$ generation

Results in Table 2 showed that Sids 12 and Misr 1 wheat cultivars responded differently to different gamma radiation doses with respect to the studied traits. Significant genotype by irradiation interaction indicated that the genotypes interacted considerably with gamma-ray changes. Under the first radiation dose, Misr 1 recorded the tallest plants. While, the shortest plants were detected by Sids 12 when it subjected to $20 \mathrm{KR}$ dose. Wheat grains irradiated with low dose (10 $\mathrm{KR}$ ) of gamma radiation revealed stimulatory effect in early heading compared with the other two doses and the control in case of Sids 12 wheat cultivar. While, the differences between $10 \mathrm{KR}$ and the control were not significant in case of Misr 1. Significant cultivar by irradiation interaction was detected for most of the studied traits (Rahm et al., 2003).

TABLE 2. Interaction between gamma radiation doses and wheat cultivars in the first mutagenic generation.

\begin{tabular}{|c|c|c|c|c|c|c|c|}
\hline Variable & $\begin{array}{c}\text { Heading } \\
\text { date } \\
\text { (day) }\end{array}$ & $\begin{array}{c}\text { Plant } \\
\text { height } \\
(\mathbf{c m})\end{array}$ & $\begin{array}{c}\text { Spike } \\
\text { length } \\
(\mathbf{c m})\end{array}$ & $\begin{array}{c}\text { No. of } \\
\text { spikelets } / \\
\text { spike }\end{array}$ & $\begin{array}{c}\text { No. of } \\
\text { grains / } \\
\text { spike }\end{array}$ & $\begin{array}{c}\text { No. of } \\
\text { spikes/ } \\
\text { plant }\end{array}$ & $\begin{array}{c}\text { Spike } \\
\text { weight } \\
(\mathbf{g})\end{array}$ \\
\hline$\underline{\text { Sids 12 }}$ & & & & & & & \\
Control & $101.3 \mathrm{~d}$ & $89.9 \mathrm{de}$ & $13.7 \mathrm{~b}$ & $22.3 \mathrm{bc}$ & $122.3 \mathrm{ab}$ & $3.8 \mathrm{~d}$ & $6.4 \mathrm{c}$ \\
$10 \mathrm{KR}$ & $95.7 \mathrm{e}$ & $91.3 \mathrm{~cd}$ & $13.6 \mathrm{~b}$ & $23.0 \mathrm{ab}$ & $127.7 \mathrm{a}$ & $5.1 \mathrm{c}$ & $7.1 \mathrm{bc}$ \\
$15 \mathrm{KR}$ & $100.7 \mathrm{~d}$ & $87.3 \mathrm{ef}$ & $14.6 \mathrm{a}$ & $23.3 \mathrm{a}$ & $120.3 \mathrm{ab}$ & $3.7 \mathrm{~d}$ & $9.4 \mathrm{a}$ \\
$20 \mathrm{KR}$ & $101.0 \mathrm{~d}$ & $84.6 \mathrm{f}$ & $14.9 \mathrm{a}$ & $23.0 \mathrm{ab}$ & $115.0 \mathrm{~b}$ & $4.4 \mathrm{~cd}$ & $7.8 \mathrm{~b}$ \\
& & & & & & & \\
Misr 1 & & & & & & & \\
Control & $103.0 \mathrm{c}$ & $97.0 \mathrm{ab}$ & $12.9 \mathrm{c}$ & $23.0 \mathrm{ab}$ & $93.0 \mathrm{c}$ & $6.2 \mathrm{~b}$ & $4.0 \mathrm{~d}$ \\
$10 \mathrm{KR}$ & $103.0 \mathrm{c}$ & $99.7 \mathrm{a}$ & $13.1 \mathrm{bc}$ & $22.9 \mathrm{ab}$ & $89.7 \mathrm{c}$ & $7.6 \mathrm{a}$ & $4.3 \mathrm{~d}$ \\
$15 \mathrm{KR}$ & $104.0 \mathrm{~b}$ & $94.8 \mathrm{bc}$ & $12.6 \mathrm{~cd}$ & $21.6 \mathrm{~cd}$ & $85.7 \mathrm{c}$ & $7.6 \mathrm{a}$ & $4.5 \mathrm{~d}$ \\
$20 \mathrm{KR}$ & $107.0 \mathrm{a}$ & $85.7 \mathrm{f}$ & $12.1 \mathrm{~d}$ & $21.5 \mathrm{~d}$ & $82.7 \mathrm{c}$ & $5.1 \mathrm{c}$ & $4.5 \mathrm{~d}$ \\
\hline
\end{tabular}

Egypt. J. Agron. 36, No. 1 (2014) 
The most favorable effect due to gamma radiation on spike length was observed under $20 \mathrm{KR}(14.9 \mathrm{~cm})$ for Sids 12 and $10 \mathrm{KR}$ for Misr $1(13.1 \mathrm{~cm})$. No. of spikelets/ spike and No. of grains/ spike for Sids 12 were maximized under $15 \mathrm{KR}$. While, the untreated plants of Misr 1 recorded the most desirable values for such traits. It is worthy to mention that the stimulatory effect of gamma irradiation for No. of spikes/ plant was observed under low dose (10 KR) in case of Misr 1. While the value of such trait was minimized under the same radiation dose in case of Sids 12 wheat cultivar. It is clearly noticed that, the mean values recorded for spike weight was significantly different under the influence of increase of gamma irradiation doses. The most desirable spike weight occurred at $15 \mathrm{KR}$ dose for Sids 12 wheat cultivar. While gamma radiation had no significant effect on spike weight of Misr 1 . These results were in general agreement with those of Rahimi \& Bahrani (2011). They found that increasing radiation exposure resulted in significant differences between wheat cultivars.

\section{Second mutagenic generation}

Varietals differences and gamma rays effects

Data presented in Table 3 indicated that the differences between Sids 12 and Misr1 were significant for all the studied traits except grain yield. Sids 12 significantly exceeded Misr 1 in five agronomic traits; plant height, spike length, number of grains/ spike, spike weight and 1000 grain weight. While, Misr 1 recorded the highest estimates for heading date, No. of spikelets/ spike and No. of spikes/ plant. The varietal differences between wheat cultivars may be due to genetical differences. In $\mathrm{M}_{2}$ generation, plant height was not significantly affected by the doses of gamma radiation. While, No. of days to heading was apparently decreased by each increment in radiation intensity when various doses were compared with control. The present findings are in agreement with those of Rahm et al. (2003), who found that $15 \mathrm{KR}$ enhanced slightly days to spike initiation. However, findings of Hassan et al. (1988) opposed these findings. They found that increase in the radiation dose resulted in the delay of heading. These types of contradictions might be due to agro-climatically changed conditions under which the experiment was conducted or due to different genetic background of the materials used (Ifraq \& Nawab, 2003).

It is clear from the present study that gamma radiations used in this study (10, 15 and $20 \mathrm{KR})$ have no significant influence on plant height. These results were closely in accordance with those reported by Madiha Jamil \& Khan (2002). They reported that 5 and $10 \mathrm{Kr}$ of gamma radiation doses reduced plant height while, 15, 20 and $25 \mathrm{KR}$ have no considerable effects on plant height. The mean values recorded for spike length were significantly higher under 15 KR compared to the control and the two doses of gamma irradiation. The cultivars mean values under $10 \mathrm{KR}$ and $20 \mathrm{KR}$ were not significantly differed from that of the control. Previous results showed that the increase in radiation intensity was associated with the gradual decrease in spike length (Ifraq \& Nawab, 2003 and Khalil et al., 1986). 


\begin{tabular}{|c|c|c|c|c|c|c|c|c|c|}
\hline 言 & $\begin{array}{l}\circ \\
\stackrel{\circ}{-}\end{array}$ & $\underset{\infty}{\infty}$ & $\stackrel{a}{a}$ & $\begin{array}{l}0 \\
0 \\
\text { i }\end{array}$ & $\stackrel{*}{*}$ & $\tilde{\mathrm{N}}$ & $\begin{array}{l}\tilde{y} \\
\ddot{y}\end{array}$ & 急 & $*$ \\
\hline 言言竞国 & 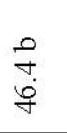 & $\underset{\stackrel{\infty}{+}}{\stackrel{\infty}{+\infty}}$ & $\begin{array}{l}\tilde{a} \\
\dot{a}\end{array}$ & $\begin{array}{l}0 \\
\infty \\
\dot{\sigma}\end{array}$ & $\stackrel{*}{*}$ & $\begin{array}{l}\pi \\
\tilde{n} \\
\stackrel{n}{n}\end{array}$ & $\begin{array}{c}2 \\
\vec{r} \\
\dot{y}\end{array}$ & $\stackrel{*}{*}$ & $\stackrel{\text { ă }}{\Rightarrow}$ \\
\hline 送 & $\stackrel{0}{\stackrel{2}{n}}$ & $\begin{array}{l}0 \\
\dot{0} \\
\dot{n}\end{array}$ & $\frac{\pi}{\sigma}$ & $\stackrel{\pi}{3}$ & $\stackrel{*}{*}$ & $\stackrel{\pi}{n}$ & $\begin{array}{l}0 \\
\mathfrak{+} \\
\dot{+}\end{array}$ & $\stackrel{*}{*}$ & $\stackrel{*}{*}$ \\
\hline 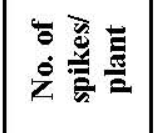 & $\stackrel{\stackrel{m}{?}}{+}$ & $\begin{array}{l}\tilde{n} \\
i n\end{array}$ & $\begin{array}{l}0 \\
\dot{0} \\
\text { in }\end{array}$ & $\frac{\text { बे }}{\vec{n}}$ & $\stackrel{*}{*}$ & 를 & $\begin{array}{l}\pi \\
\stackrel{2}{2} \\
0\end{array}$ & $\stackrel{*}{*}$ & $*$ \\
\hline 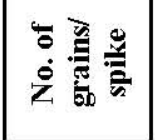 & $\begin{array}{l}8 \\
0 \\
0 \\
\infty\end{array}$ & $\frac{0}{\infty}$ & $\begin{array}{l}\tilde{\sigma} \\
\stackrel{0}{8} \\
\&\end{array}$ & $\begin{array}{l}0 \\
\text { के } \\
\dot{8}\end{array}$ & $\stackrel{*}{*}$ & $\begin{array}{l}\tilde{0} \\
\stackrel{0}{0} \\
\Omega\end{array}$ & $\begin{array}{r}\stackrel{0}{0} \\
\stackrel{8}{5}\end{array}$ & $\stackrel{*}{*}$ & $*$ \\
\hline 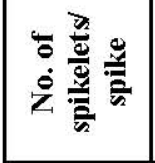 & $\begin{array}{l}8 \\
n \\
\\
\end{array}$ & $\stackrel{0}{\stackrel{y}{\mathrm{~d}}}$ & $\begin{array}{l}\tilde{\sigma} \\
\stackrel{+}{4} \\
\end{array}$ & $\begin{array}{l}\text { है } \\
\text { ते } \\
\text { ते }\end{array}$ & $\stackrel{*}{*}$ & $\stackrel{0}{m}$ & $\begin{array}{l}\stackrel{\pi}{+} \\
\stackrel{\sim}{\sim} \\
\end{array}$ & $\stackrel{*}{*}$ & $\stackrel{*}{*}$ \\
\hline 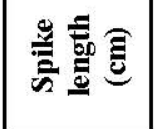 & $\stackrel{0}{i}$ & $\stackrel{0}{\vec{i}}$ & $\stackrel{\pi}{a}$ & $\begin{array}{l}\stackrel{0}{n} \\
\stackrel{3}{7}\end{array}$ & $\stackrel{*}{*}$ & $\begin{array}{l}\tilde{D} \\
\stackrel{\leftrightarrow}{\longrightarrow}\end{array}$ & $\stackrel{0}{9}$ & $\stackrel{*}{*}$ & $*$ \\
\hline 言言总要 & $\begin{array}{c}m \\
\infty \\
\infty\end{array}$ & $\begin{array}{l}\infty \\
\dot{+}\end{array}$ & $\hat{\infty}$ & $\vec{\infty}$ & $\stackrel{2}{z}$ & $\frac{\ddot{n}}{\infty}$ & $\begin{array}{l}\vec{n} \\
\ddot{\infty} \\
\dot{\infty}\end{array}$ & $\stackrel{*}{*}$ & $\stackrel{*}{*}$ \\
\hline 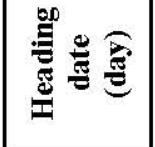 & $\begin{array}{l}\ddot{0} \\
\stackrel{0}{\sigma}\end{array}$ & $\begin{array}{l}0 \\
\tilde{n} \\
\tilde{a}\end{array}$ & $\begin{array}{l}\dot{n} \\
\ddot{n} \\
\tilde{n}\end{array}$ & $\begin{array}{l}\dot{n} \\
\stackrel{\alpha}{\alpha}\end{array}$ & $\stackrel{*}{*}$ & $\begin{array}{l}0 \\
\tilde{n}\end{array}$ & $\begin{array}{l}\tilde{D} \\
\tilde{n} \\
\delta\end{array}$ & $\stackrel{*}{*}$ & $\stackrel{2}{\Rightarrow}$ \\
\hline 就 & $\begin{array}{l}\overrightarrow{0} \\
\text { 音 } \\
\text { ن }\end{array}$ & 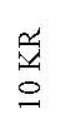 & $\begin{array}{l}\stackrel{x}{x} \\
\text { an }\end{array}$ & 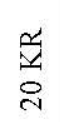 & 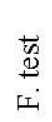 & 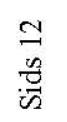 & $\overrightarrow{\vec{n}}$ & 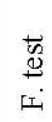 & $\begin{array}{l}0 \\
凶 \\
0\end{array}$ \\
\hline 䏤 & & & 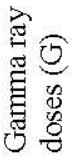 & & & & 龸 & & 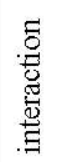 \\
\hline
\end{tabular}

Egypt. J. Agron. 36, No. 1 (2014) 
Generally, the increase in radiation intensity (15 and $20 \mathrm{KR}$ ) was associated with the increase in No. of spikelets/ spike and No. of grains/ spike. In this connection, Madiha Jamil \& Khan (2002) reported that subjecting wheat cultivars to $20 \mathrm{KR}$ gamma radiation dose resulted in the highest No. of seeds/ spike. Also, number of seeds/ spike under 5, 10, and 15 KR were more than of the control. By comparing the mean values of various doses it was found that No. of spikes/ plant was significantly improved under irradiated plants compared with the control. It indicates that improvement in quantitative traits would be possible though selection in mutated generation from gamma irradiation. The present results were in accordance with those reported by Morad et al. (2011).

Wheat grains irradiated with higher doses (15 and $20 \mathrm{KR})$ surpassed the other treatments and the control in spike weight. Increasing spike weight under such treatments may be due to an increase in No. of spikelets and No. of grains/ spike and 1000-grain weight. Subjecting wheat grains to low doses of gamma radiation improved 1000-grain weight and grain yield/ plant. Gamma radiation increased grain yield through enhancing other yield components; No. of spikes/ plant, No. of grains/ spike, spike weight and 1000 -grain weight. These results confirmed those reported by Singh \& Data (2009). They reported that gamma radiation increased grain yield due to an increase in No. of ears bearing tillers and grain number. Rahimi \& Bahrani (2011) exposured wheat grains to four gamma radiation doses; 25, 50, 75 and $100 \mathrm{~Gy}$. They found that 25 and 50 Gy produced higher grain yields than the control. Increasing grain yield was mainly due to an increase in No. of spikes/ plant. Increasing yield in irradiated materials over the control could be attributed to the probability that irradiation treatments create a state of heterogeneity and activation of some genes that led to increase yield above untreated materials (Abdel-Hady \& Ahmed, 2004). From the aforementioned results of $\mathrm{M}_{2}$ generation it could be concluded that low dose of gamma radiation (10 KR) improved grain yield, 1000-grain weight and No. of spikes/ plant. While, $15 \mathrm{KR}$ was the most beneficial radiation dose for spike length, No. of spikelets / spike, No. of grains/ spike, spike weight as well as 1000 -grain weight. However, the highest dose $(20 \mathrm{KR})$ was the most desirable for early heading and it also was in parallel with $15 \mathrm{KR}$ for No. of spikelets/ spike, No. of grains/ spike and spike weight. Previous results showed that the most beneficial dose was $20 \mathrm{KR}$. The impact of this dose was promising in days to heading and enhancement in yield and yield contributing traits (Shubhra et al., 2013). Other results showed that $150 \mathrm{~Gy}$ treatment increased significantly growth characters such as, plant height, No. of spikes/ plant, 1000-grain weight compared with the control. While, 450 Gy recorded the lowest estimates for the aforementioned traits (Abdel-Hady \& Ali, 2006) 
Effect of interaction between cultivars and gamma rays in $M_{2}$ generation

As shown in Table 4 the interaction between wheat cultivars and gamma rays were significant for all the studied characters except for heading date and 1000-grain weight. At $15 \mathrm{KR}$ Sids 12 gave significant increase and surpassed Misr 1 in spike length, No. of grains/ spike and spike weight. However, non-significant differences in the mean values for No. of spikelets/ spike were observed between Sids 12 and Misr1 under the same radiation dose. On the other hand, when wheat grains exposured to low dose of gamma radiation $(10 \mathrm{KR})$, Misr 1 wheat cultivar produced the highest estimates of plant height, No. of spikes/ plant and grain yield.

Previous results showed that the interaction between wheat cultivars and gamma ray doses in $\mathrm{M}_{2}$ were significant for grain yield and yield components (Abdel-Hady $\&$ Ali, 2006). These results were also in general agreement with those reported by Morad et al. (2011). They reported that all cultivars responded differently to different gamma radiation doses with respect to the studied traits. Ifraq \& Nawab (2003) noted that the cultivars mean values differed significantly under the influence of gamma rays doses.

TABLE 4. Interaction between gamma radiation doses and wheat cultivars in the second mutagenic generation.

\begin{tabular}{|l|c|c|c|c|c|c|c|}
\hline Variable & $\begin{array}{c}\text { Plant } \\
\text { height } \\
(\mathbf{c m})\end{array}$ & $\begin{array}{c}\text { Spike } \\
\text { length } \\
(\mathbf{c m})\end{array}$ & $\begin{array}{c}\text { No. of } \\
\text { spikelets } / \\
\text { spike }\end{array}$ & $\begin{array}{c}\text { No. of } \\
\text { grains / } \\
\text { spike }\end{array}$ & $\begin{array}{c}\text { No. of } \\
\text { spikes/ } \\
\text { plant }\end{array}$ & $\begin{array}{c}\text { Spike } \\
\text { weight } \\
(\text { g) }\end{array}$ & $\begin{array}{c}\text { Grain } \\
\text { yield } \\
\text { (g/plant })\end{array}$ \\
\hline Sids 12 & & & & & & & \\
Control & $84.5 \mathrm{~cd}$ & $12.7 \mathrm{bc}$ & $20.3 \mathrm{c}$ & $92.8 \mathrm{c}$ & $3.4 \mathrm{~d}$ & $6.5 \mathrm{c}$ & $19.3 \mathrm{~cd}$ \\
$10 \mathrm{KR}$ & $80.4 \mathrm{de}$ & $12.6 \mathrm{bc}$ & $21.3 \mathrm{bc}$ & $90.2 \mathrm{~d}$ & $3.8 \mathrm{~d}$ & $6.4 \mathrm{c}$ & $25.8 \mathrm{~b}$ \\
$15 \mathrm{KR}$ & $81.6 \mathrm{de}$ & $13.8 \mathrm{a}$ & $22.1 \mathrm{ab}$ & $113.0 \mathrm{a}$ & $3.6 \mathrm{~d}$ & $8.4 \mathrm{a}$ & $22.0 \mathrm{c}$ \\
$20 \mathrm{KR}$ & $79.6 \mathrm{e}$ & $13.0 \mathrm{~b}$ & $21.4 \mathrm{bc}$ & $102.5 \mathrm{~b}$ & $3.9 \mathrm{~d}$ & $7.6 \mathrm{~b}$ & $21.8 \mathrm{c}$ \\
& & & & & & & \\
Misr 1 & & & & & & & \\
Control & $86.0 \mathrm{bc}$ & $12.3 \mathrm{~cd}$ & $22.8 \mathrm{a}$ & $78.4 \mathrm{e}$ & $5.2 \mathrm{c}$ & $4.8 \mathrm{~d}$ & $18.7 \mathrm{~d}$ \\
$10 \mathrm{KR}$ & $89.2 \mathrm{ab}$ & $11.5 \mathrm{e}$ & $21.2 \mathrm{bc}$ & $73.6 \mathrm{f}$ & $7.3 \mathrm{a}$ & $4.8 \mathrm{~d}$ & $30.3 \mathrm{a}$ \\
$15 \mathrm{KR}$ & $92.2 \mathrm{a}$ & $12.0 \mathrm{cde}$ & $22.6 \mathrm{a}$ & $79.1 \mathrm{e}$ & $6.3 \mathrm{~b}$ & $5.0 \mathrm{~d}$ & $21.9 \mathrm{c}$ \\
$20 \mathrm{KR}$ & $90.7 \mathrm{a}$ & $11.9 \mathrm{de}$ & $23.1 \mathrm{a}$ & $79.3 \mathrm{e}$ & $6.4 \mathrm{~b}$ & $5.0 \mathrm{~d}$ & $22.1 \mathrm{c}$ \\
\hline
\end{tabular}

\section{Genetic parameters}

Estimates of genetic parameters (in $\mathrm{M}_{2}$ generation) as genotypic variance $\left(\sigma^{2} \mathrm{~g}\right)$, phenotypic (PCV), and genotypic (GCV) coefficients of variability, broad sense heritability ( $h^{2}$ b.s) and genetic advance from selection $(\Delta \mathrm{g})$ are presented in Table 5. The results showed that the genotypic variance $\left(\sigma^{2} \mathrm{~g}\right)$ was significant for all the studied traits for irradiated and non irradiated plants except for spike length and grain yield/ plant in case of the control. Indicating

Egypt. J. Agron. 36, No. 1 (2014) 
wide range of genetic variability between Sids 12 and Misr 1 especially under irradiation treatments. It is worthy to mention that the genotypic variance under irradiated treatments was folded several times compared with non treated plants. Phenotypic coefficient of variability was, in general, higher than genotypic coefficient of variability either in irradiated or the control plants, indicating a great role of gamma irradiation on the expression of different traits. Also, such estimates were doubled several times in case of treated plants compared with non-treated. This was true for all studied traits except for days to heading where the estimates of GCV were close to PCV. No. of spikes/ plant, spike weight, No. of grains/ spike and grain yield recorded the highest estimates for PCV $(72.9,53.7,36.9$ and 30.2) and GCV (40.8, 28.2, 17.4 and 12.9) for the aforementioned characters, respectively. Indicating that these traits might be more genotypically predominant and it would be possible to achieve further improvement from them through selection. Similar results were reported by Choudhary \& Das (1988).

Results in Table 5 showed that heritability estimates in broad sense under gamma radiation were in general higher than such estimates in control plants for all the studied traits. Previous results showed that the expected PCV was higher than GCV in $\mathrm{M}_{2}$ generation for all the studied characters after irradiation with gamma rays with a rate of $15 \mathrm{KR}$ (Mahantashivayogayya et al., 2003), Indicating further improvement through selection in mutated population. Results also showed that heading date, No. of spikelets/ spike, No. of spikes/ plant and spike weight exhibited the highest broad sense heritability estimates in both irradiation $(90.6,81.7,86.9$ and $91.3 \%)$ and non irradiated plants $(65.9,54.0,54.1$ and $53.5 \%)$ for the aforementioned four characters, respectively. Similar results were obtained by Morad et al. (2011). They reported that heritability values in $\mathbf{M}_{2}$ generation were high reached to more $90 \%$, indicating the efficiency of gamma radiation doses in inducing genetic variation allowing the wheat breeder to improve the wheat yield and its attributes through this method. Kassem \& Naser (1995) found that subjecting wheat grains to $25 \mathrm{KR}$ increased the values of phenotypic and genotypic coefficients of variation as well as heritability estimates for most of the studied characters.

Results in Table 5 showed that the expected genetic advance from selection, as percentage of mean, for non treated plants ranged from 4.1 to $45.4 \%$ for plant height and No. of spikes, respectively. While, it ranged from 7.97 to $100.9 \%$ for heading date and spike weight, respectively under irradiated plants. The desirable genetic advance was found to be associated with high heritability estimates in case of No. of spikes/ plant and spike weight. The coefficient of genetic variability together with heritability estimates gave a reliable picture of genetic advance to be expected from selection. 


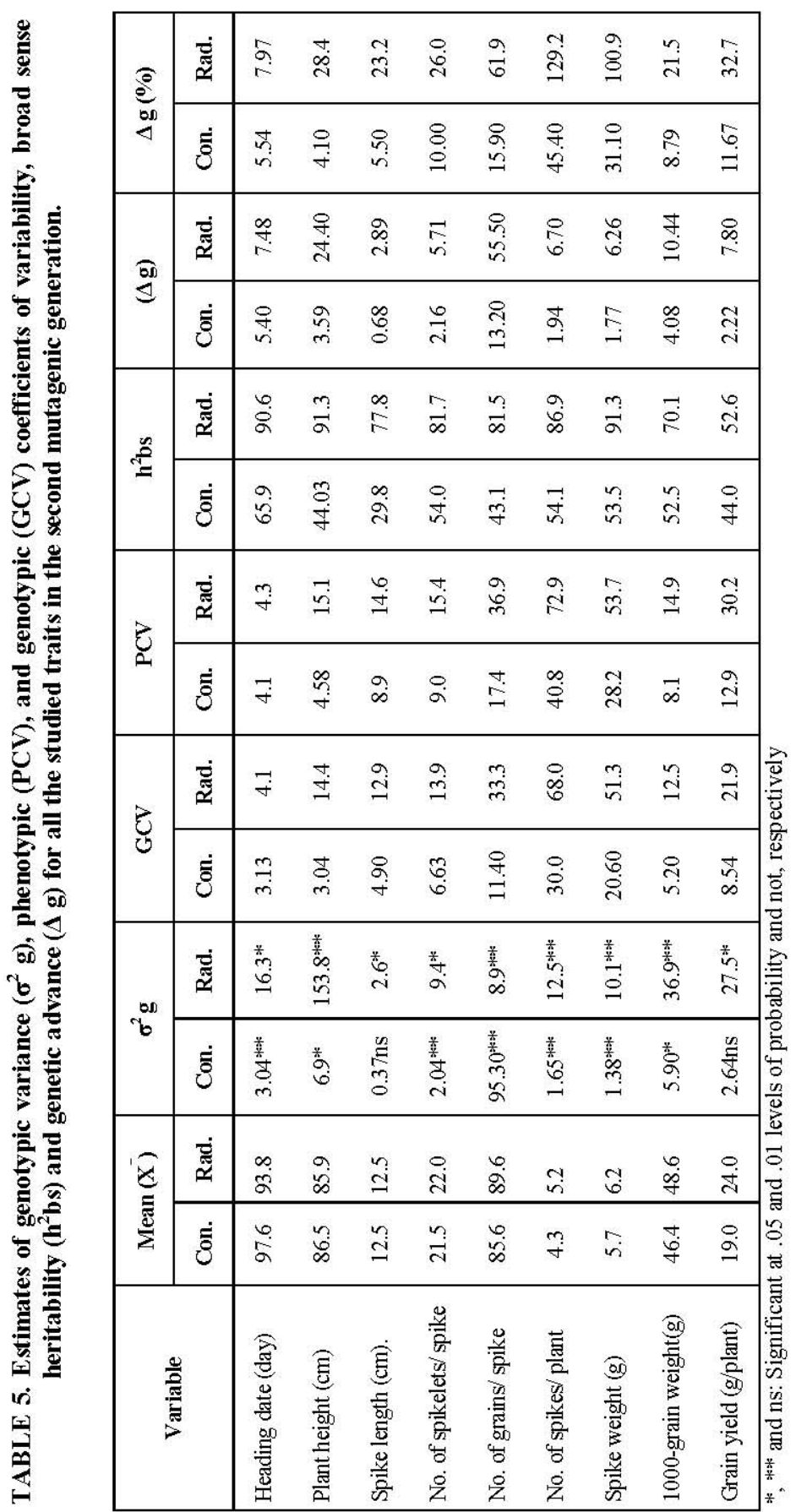

Egypt. J. Agron. 36, No. 1 (2014) 


\section{References}

Abdel-Hady, M. S. and Ahmed, M. F. (2004) Detection of gamma rays influence in Triticum aestivum L. by some agronomic traits and biochemical genetic analysis. Egypt Journal of Agronomy, 26, 77-87.

Abdel-Hady, M. S. and Ali, Z. A. (2006) Effect of gamma irradiation on wheat immature culture regenerated plants. Journal of Applied Science Research, 2 (6), 310316.

Amin, A. A. (2003) Physiological effect of gamma irradiation and kinetin on growth, yield and chemical constituents of wheat. Egypt Journal of Applied Science, 18 (6), 34-49.

Azer, S. A. (2001) Radio-sensitivity of some wheat cultivars irradiated with gamma rays. Annals of Agric. Sci. Ain Shams Univ., Cairo, 46(2), 663-679.

Brunner, H. (1995) Radiation induced mutations for plant selection. Applied Radiation and Isotopes, 46 (6-7), 589-594.

Burton, G. W. (1952) Quantitative inheritance in grasses. Proc. $3^{\text {rd }}$ Int. Grassid Congr. 1, 227-283.

Choudhary, P. D. and Das, P. K. (1988) Genetic variability and correlation between quality and physio-chemical properties of high grain quality in rice. Chinese J. Rice Sci. 11 (2), 70-76.

Duncan, D.B. (1955) Multiple F-test. Biometrics, 11, 1-41.

Farag, I. A. A. and El-Khawaga, A. A. H. (2013) Influence of gamma irradiation and nitrogen fertilizer levels on Gemmeiza-9 wheat cultivar. Yield and its attributes. Arab Journal of Nuclear Science and Applications, 46 (2), 363-371.

Hassan, S., Mohammed, T., Jabbar, A. and Ali, I. (1988) Effect of gamma rays and sodium azide on some yield components of wheat. The Nucleus, 25, 27-29.

Irfaq, M. and Nawab, K. (2003) A study to determine the proper dose of gamma radiation for inducing beneficial genetic variability in bread wheat (Triticum aestivum L.). Asian Journal of Plant Sciences, 2 (13), 999-1003.

Johnson, H. F., Robinson, H. F. and Comstock, R. E. (1955) Estimates of genetic and environmental variability in soybean. Agron. J. 47, 314-318.

Kassem, M. and Naser, S. (1995) Effect of gamma irradiation on growth characters, yield attributes and genetic variation for bread wheat (Triticum aestivum vulgare L.) Zagazig Journal of Agriculture Research, 22 (5), 1195-1206.

Khalil, S. J., Rehman, S., Afridi, K. and Jan, M. T. (1986) Damage induced by gamma radiation in morphological and chemical characteristics of barley. Sarhad J. Agri. 2 , 45-54. 
Kim, J. Y., Kim, D. Y., Jang, C.S. and Seo, Y. W. (2007) Development of molecular markers for bentazone-resistant wheat (Triticum aestivum L.) induced by gamma-ray irradiation. Journal of Korean Physical Society, 50 (5), 1499-1505.

Kozub, N. A., Sozinov, I. A., Blume, Y. B. and Sozinov, A. A. (2013) Study on the effects produced by gamma irradiation of common wheat $F_{1}$ seeds using gliadins as genetic markers. Cytology and Genetics, 47(1).

Lapochkina, I. F. (1998) Cytogenic and morphological features of bread wheat hybrids obtained with the use of irradiated pollen of Aegilops triuncialis L. Genetica (Moskva) 34, 1263-1268.

Madiha Jamil and Khan, U. Q. (2002) Study of genetic variation in yield components of wheat cultivar Bukhtwar-92 as induced by $\mathrm{Y}$ radiation. Asian Journal of Plant Science, 1, 579-580.

Mahantashivayogayya, K., Hanchinal, R. R. and Salimath, P. M. (2003) Variability studies in dicoccum wheat (Triticum dicoccum Schrank Suhulb) following hybridization and hybridization followed by mutagensis . Karnataka J. Agric. Sci. 16 (4), 556-559.

Maity, J. P., Mishra, D., Chakraborty, A., Saha, A., Santra, S.C. and Chanda, S. (2005) Modulation of some quantitative and qualitative characteristics in rice (Oryza sativa L.) and Mung (Phaseolus mungo L.) by ionizing radiation. Radiat. Phys. Chem. 74, 391-394.

Melki, M. and Marouni, A. (2009) Effects of gamma rays irradiation on seeds germination and growth of hard wheat. Environ Chem. Lett., 10.1007/s 10311-0090222-1.

Morad, A. A., El-Hashah, E. F., Hager, M. A. and Zaazaa, E. I. (2011) Inheritance of yield and yield components for mutated population using gamma irradiation in some bread wheat cultivars. Agricultural Research Journal; Suez Canal University 11(2), 7-16

Rachovska, G. and Dimova, D. (2000) Effect of sodium azide and gamma rays on $\mathrm{M}_{1}$ quantitative characteristics of the productivity and their connection with $\mathrm{M}_{2}$ mutation changes in winter common wheat. Rasteniev dni Nauki, 37 (7), 413-419.

Rahimi, M. M. and Bahrani, A. (2011) Influence of gamma irradiation on some physiological characteristics and grain protein in wheat (Triticum aestivum L.). World Applied Sciences Journal, 15 (5), 654-659.

Rahm, D., Muhammad, Q., Khalil, A. and Sahah, J. (2003) Study of days taken to earing intiation and earing completion in $\mathrm{M}_{1}$ generation of different wheat genotypes irradiated with various doses of gamma radiation. Asian Journal of Plant Sciences, 2 (12), 894-896.

Shubhra, S., Marker, R. M., Abrar, Y. B. and Akhilesh, K. (2013) Induced mutation through gamma irradiation at different doses to create genetic variability and study the improvement in yield and yield attributes of genotype HD 2867. Trends in BioSciences, 6(1), 65-67. 
Singh, B. and Datta, P. S. (2009) Gamma irradiation to improve plant vigor, grain development and yield attributes of wheat. Radiation Physics and Chemistry, doi:10.1016/j. radphyschem. 2009.05.025.

Singh, R. K. and Chaudhary, B. D. (1985) "Biometrical Methods in Quantitative Genetic Analysis". Kalyani Publishers, New Delhi.

(Received 8/4/2014; accepted 16/6/2014)

تاثير المعاملة باثعة جاما على الاداء و بعض المباثلة المعالم و المقاييس

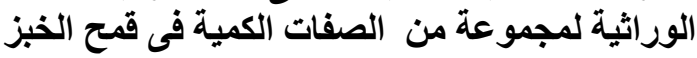

$$
\begin{aligned}
& \text { ابر اهيم سعد محمد الاجوى و محمد صبحى حتحوت" }
\end{aligned}
$$

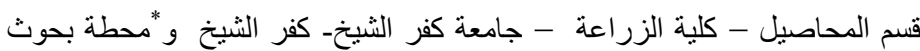

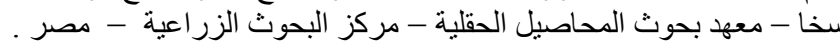

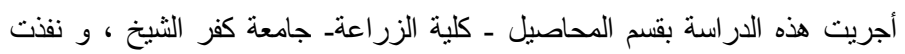

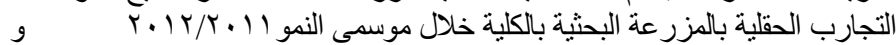

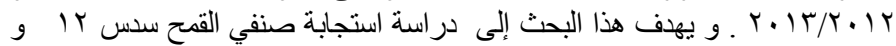

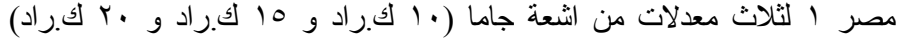

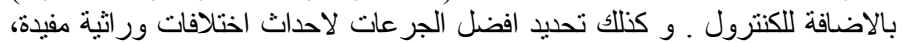

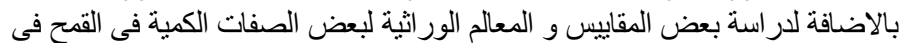

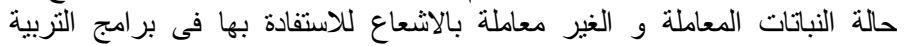

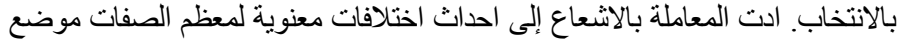

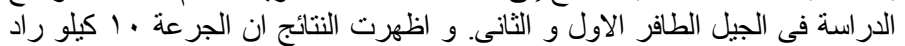

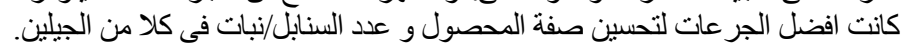

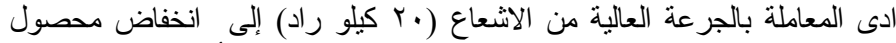

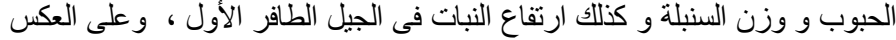

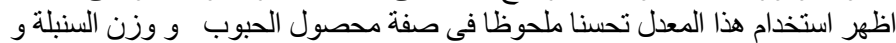

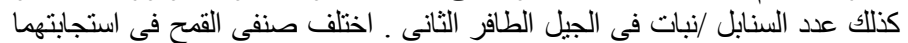

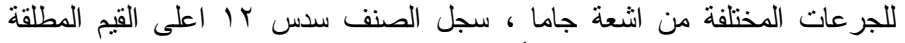

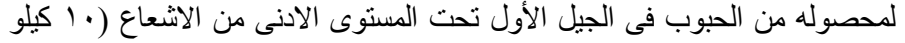

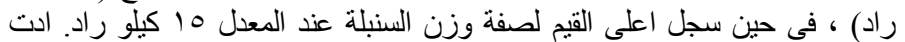

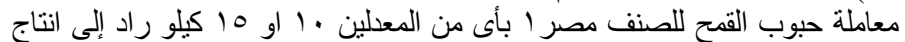

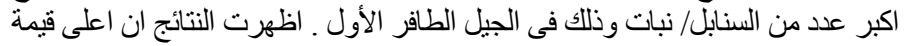

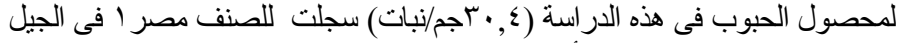

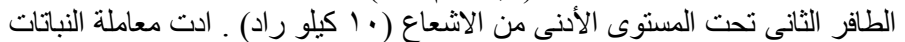

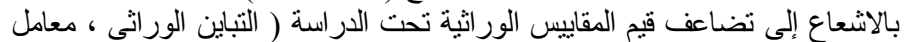

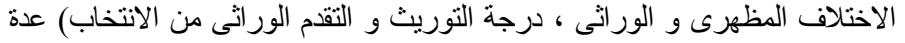

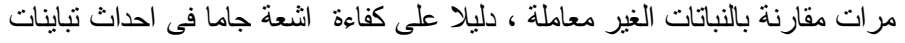

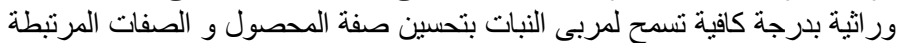

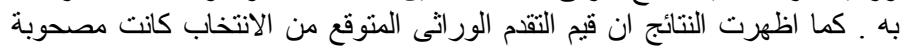

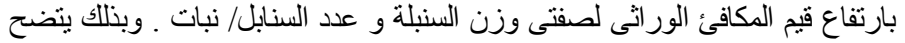

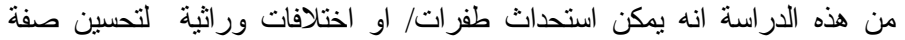
المحصول و غيرها من الصفات الكمية فى القمح . 